COBO ROMERO, Francisco, DEL ARCO BLANCO, Miguel Ángel y ORTEGA LÓPEZ, Teresa, "The Stability and Consolidation of the Francoist Regime. The case of Eastern Andalusia, 1936-50”, Contemporary European History, 20, 1, 2011, pp. 37-59.

\title{
THE STABILITY AND CONSOLIDATION OF THE FRANCOIST REGIME. THE CASE OF EASTERN ANDALUSIA, 1936-1950
}

\author{
Francisco Cobo Romero \\ Miguel Ángel del Arco Blanco \\ Teresa María Ortega López* \\ University of Granada
}

The authoritarian regimes in interwar Europe were not traditional dictatorships, merely imposed from above on an immobile and passive society. On the contrary: their emergence, installation and consolidation came about due to the mobilisation of different social groups who, through their actions and perceptions, constituted and gave life to the new states. That is why, in order to understand their true nature and the reasons behind their creation and consolidation, we need to analyse the interaction between those regimes and the societies in which they took root.

In our view, as regards internal factors, the stabilisation and later consolidation of Franco's regime can be explained by the interpenetration of society and the institutions of the "New State" in three overlapping areas. Firstly, in the sphere of the shared and unifying culture of the community of Civil War victors, forged by means of the construction of a sublimated imaginary. This imaginary was founded on two great myths: that of victory, which conferred a regenerative and sacred nature on the military struggle, and that of the Refundación Nacional (National Refoundation), which granted the dictatorial regime that arose from the Civil War a new stage of glory and splendour, built on the ruins of the "ignominious" Republican experience. Secondly, as regards repression, which had the decisive collaboration of those supporting Francoism and that would destroy any possible opposition on the part of their potential enemies. Francoism would proclaim itself to be the new political order that would return the nation its lost greatness and would bring relentless justice to enemies of the "Fatherland" ("Patria"). The dehumanised image of the vanquished that the dictatorship managed to impose came together with the heralding of a new era in which there would only be space for the religious, Catholic and spiritualised values of the Eternal Fatherland. We think that this set of idealisations supported the creation of a new

\footnotetext{
* Francisco Cobo Romero (드obo@ugr.es), Teresa María Ortega (tmortega@ugr.es), Miguel Ángel del Arco (maarco@ugr.es). Department of Contemporary History, Faculty of Philosophy and Arts. University of Granada. Campus de Cartuja s/n, 18071, Granada (Spain).

The Spanish Ministerio de Innovación y Ciencia has funded the research drawn on for this article (Ref: HAR2009-07487).
} 
COBO ROMERO, Francisco, DEL ARCO BLANCO, Miguel Ángel y ORTEGA LÓPEZ, Teresa, "The Stability and Consolidation of the Francoist Regime. The case of Eastern Andalusia, 1936-50”, Contemporary European History, 20, 1, 2011, pp. 37-59.

emotional climate of identification with the new regime's essential aims, while it probably contributed to the adoption by many Spaniards of an attitude of adhesion to, and even loyal cooperation with, the "New State" and its repressive organs. ${ }^{1}$ Thirdly and finally, in the socioeconomic sphere, where those making up the groups supporting the "New State" would see their personal interests fulfilled, while the defeated would be enclosed in a maze of misery and silence, abandoning any political concerns and concentrating on survival.

It is commonly accepted nowadays that, as with other interwar authoritarian regimes, Francoism enjoyed a broad consensus among the population. ${ }^{2}$ However, as in other European cases, the population's attitudes were not divided in a Manichean or bipolar way between consensus and dissent. ${ }^{3}$ There was a broad range of behaviour, from unconditional agreement to support with some moral or political disagreements, to acceptance, to passiveness, to demobilisation, to accommodation, to dissent shown in the private sphere and even direct opposition to the regime. ${ }^{4}$ However, as we propose in this work, Francoism's policies would manage to achieve stability for the regime, ensuring support among a heterogeneous set of social groups, as well as eliminating any signs of opposition from the dissidents' side. Furthermore, we maintain that the consent which the regime enjoyed among a large section of the population existed alongside the depoliticisation and repression of possible opponents, and their forced withdrawal to the interior sphere of activity in search of support that would allow them to survive the terrible economic conditions of the post-war period. Therefore, it is impossible to understand Francoism without the terms "consent" and "repression", which were not opposites, but a consequence of each other: both would be present in the interconnection between the regime's institutions and society, in the active participation of the victors in the work of repression, as well as the punishment meted out by these to the vanquished.

It is in the local sphere, in viewpoints "from below", where we can most vividly see the interaction between the regime and society taking place. With this perspective, we focus our study on the south of Spain: we assess the emergence of a "culture of victory" in different

\footnotetext{
${ }^{1}$ See Peter Anderson, The Francoist Military Trials. Terror and Complicity, 1939-1945 (New York and London: Routledge, 2010).

${ }^{2}$ Manuel Ortiz Heras, 'Historia social en la dictadura franquista: apoyos sociales y actitudes de los españoles', Spagna Contemporanea, 28 (2005), 169-85.

3 Antonio Cazorla, 'Sobre el primer franquismo y la extensión de su apoyo popular', Historia y política, 8 (2002), 312; Ismael Saz, Fascismo y Franquismo (Valencia: Prensas Universitarias de Valencia, 2004), 174-7.

${ }^{4}$ Jordi Font, ;Arriba el campo!: primer franquisme i actituds polítiques en l'ámbit rural nord-catalá (Girona: Diputación de Girona, 2001), 227-38.
} 
COBO ROMERO, Francisco, DEL ARCO BLANCO, Miguel Ángel y ORTEGA LÓPEZ, Teresa, "The Stability and Consolidation of the Francoist Regime. The case of Eastern Andalusia, 1936-50”, Contemporary European History, 20, 1, 2011, pp. 37-59.

Andalusian cities of the Francoist rearguard during the Civil War. Then, already focussing on different locations and provinces in eastern Andalusia (see Map 1), we attempt to show that this culture was a key element in creating a "national community". This is to be done firstly through the analysis of Francoist repression and the participation in this of the victors and, secondly, through the application of an autarchical political economy that punished the defeated and acted in the interests of the victors. By means of this approach to the local, the links existing between local realities and the regional and national political reality can be brought into relief. It is in the interaction between these spheres that the Francoist regime got underway, both culturally and socially speaking.

[MAP 1]

\section{The "cultural community" of the victors}

The Imaginary centred on the Civil War and the construction of an ultra-nationalist Francoist identity.

From the very beginning of the 1936-1939 war, the rebels built up a great arsenal of mytholigised stories and imaginaries. The imaginaries were created to justify the "uprising" and were intended to grant meaning to their own Fascistised, anti-Republican and antidemocratic political project. The sublimated idealisation of the Civil War by the rebel group was wrapped in a collection of cultural, mythical and symbolic components, imported from the most refined traditions of the anti-liberal and anti-parliamentarian right ${ }^{5}$. During the conflict, all these discourses ${ }^{6}$, myths and symbols would end up becoming cornerstones of the legitimising ideology of the Francoist "New State".

The importance of the historical construction of the Fascistised and anti-democratic right's political languages and the propaganda messages over the course of the Civil War can be understood much better by using a "culturalist" approach. We view as unavoidable the dissection of the discursive components and the interpretative agencies that modelled the

\footnotetext{
${ }^{5}$ Ismael Saz, España contra España. Los nacionalismos franquistas (Madrid: Marcial Pons, 2003), 77-99 and 105-55. Also: Pedro Carlos González Cuevas, Acción española. Teología política y nacionalismo autoritario en España, 1913-1936 (Madrid: Tecnos, 1998) and by the same author, Historia de las derechas españolas. De la Ilustración a nuestros días (Madrid: Biblioteca Nueva, 2000).
} 
COBO ROMERO, Francisco, DEL ARCO BLANCO, Miguel Ángel y ORTEGA LÓPEZ, Teresa, "The Stability and Consolidation of the Francoist Regime. The case of Eastern Andalusia, 1936-50”, Contemporary European History, 20, 1, 2011, pp. 37-59.

individual and collective behaviour of those supporting the dictatorial regime installed after the defeat of democracy during the Civil War. The allegorical and sublimated recreation of the war created by the rebels was manifested through a dense sedimentation of discursive recreations and metanarratives with a strongly mythogenic capacity. Almost all these elements, with their idealised and symbolic nature, powerfully contributed to building the perceptions by which the individual or group actors interpreted the conflict's nature or justified the unavoidable use of extreme violence against an enemy designated as perverse and inhuman. It is clear that subjectivity and perceptions condition individual decisions and actions. Furthermore, social imaginaries define and order the way in which actors perceive, codify and interpret the reality that surrounds them, giving meaning to their perception of experiences and allowing them to have a personalised understanding of "their world"7. All this, then, acquires a special meaning if we accept the premise that the individual and group actors carry out their own decisions profoundly influenced by a dense network of highly idealised mental recreations and cultural perceptions, which, in each case, takes a specific linguistic and conceptual formulation ${ }^{8}$.

The dehumanising images of the leftist enemy and the discourses discrediting the Republic came together in the midst of the climate of terror, death and revenge that took over in the rebel rearguard, in an exalted interpretation of the 1936-1939 conflict. Once the "New State" was in place throughout the national territory, the complex mixture of symbols, imaginaries, languages and cults that extolled the war's regenerative nature allowed the creation of the myth of the Nation's sacred sacrifice and the salvation and purification granted by death. The sum of all these imaginaries, given a strong emotive and mythogenic charge, managed to invest the Francoist regime with a sanctified and regenerative halo. The idealised vision that identified Francoism as the starting point of a glorious stage in the resurgence of the Fatherland became a powerful instrument used by the dictatorship to instil trust and support among an extensive and mixed range of individuals and social groups. It was this

\footnotetext{
${ }^{6}$ See Miguel Ángel Cabrera, Postsocial History. An Introduction (Lanham, Maryland, Oxford: Lexington Books, 2004), 22-4.

7 Jordi Font, "Nosotros no nos cuidábamos de la política". Fuentes orales y actitudes políticas en el Franquismo. El ejemplo de una zona rural, 1939-1949', Historia Social, 49 (2004), 49-66; see particularly pp. 52-4.

${ }^{8}$ Miguel Ángel Cabrera, Historia, lenguaje y teoría de la sociedad (Madrid: Cátedra-Universitat de Valencia, 2001), 47-51; Gabrielle M. Spiegel, 'La historia de la práctica: nuevas tendencias en historia tras el giro lingüístico', Ayer, 62 (2006), 19-50, see 24-7; Andreas Reckwitz, 'Toward a Theory of Social Practices. A development in culturalist theorizing', in Gabrielle M. Spiegel, ed., Practicing History. New Directions in Historical Writing after the Linguistic Turn (London \& New York, Routledge, 2005), 249-52; William H.
} 
COBO ROMERO, Francisco, DEL ARCO BLANCO, Miguel Ángel y ORTEGA LÓPEZ, Teresa, "The Stability and Consolidation of the Francoist Regime. The case of Eastern Andalusia, 1936-50", Contemporary European History, 20, 1, 2011, pp. 37-59.

large part of the population that played a decisive role both in the aid given when it came to repressive violence against the vanquished and in the maintenance of the dictatorial "New State".

In short, Francoism was built on an idealised reconstruction of the war and the victory that achieved a very probable capacity to seduce and persuade the upper classes, of course, but also intermediate and even popular social groups that were most harmed by the strikes and social upheaval of the Republican years, by the overturn of traditional and religious values, or by the excesses of the revolution carried out in the Republican rearguard during the Civil War. This mythified reconstruction was based on a regenerative image of the war; on the myth of victory against the Fatherland's enemies, represented by the "abominable" democratic regime of the Second Republic; and an extensive programme of re-Catholicisation and re-establishment of the traditional Spain. Through the construction of the myths of victory (over the enemies of Eternal Spain) and of the Refounding of the Nation (carried out after the war), Francoism favoured the modelling of a culture of identity among the victors, carving out a stereotyped and accusatory image of the "pernicious" Republican experience and contributing to forging a specific anti-democratic memory.

The anti-left Imaginary and the gestation of anti-Republican memory.

The key ideas that acted as founding elements of the victors' ideological cohesion underwent an accelerated process of bias and stylisation over the course of the war. The military confrontation was conceived as the supreme and definitive attack necessary to exterminate that monstrous enemy -the anti-Spain- that threatened the Fatherland. The military victory over the enemies of the native land would put an end, once and for all, to a prolonged decadence of the national spirit which had been underway since, at least, the first construction of the liberal State at the beginning of the $19^{\text {th }}$ century. This process of moral degeneration was seen as having intensified to an intolerable pace with the arrival of the Republican regime and its insidious permissiveness and unacceptable collusion with the growth and spread of the Republican, Marxist and anarchist lefts. From this perspective, those responsible for such a reprehensible phenomenon of national neglect should be definitively

Sewell, 'The Concept(s) of Culture', in Victoria Bonnell and Lynn Hunt, eds, Beyond the cultural turn. New directions in the study of society and culture (Berkeley: University of California Press, 1999), 35-61. 
COBO ROMERO, Francisco, DEL ARCO BLANCO, Miguel Ángel y ORTEGA LÓPEZ, Teresa, "The Stability and Consolidation of the Francoist Regime. The case of Eastern Andalusia, 1936-50”, Contemporary European History, 20, 1, 2011, pp. 37-59.

exterminated by applying extreme and "purifying" violence, such as that triggered by the 1936 "glorious uprising",

The anti-leftist and dehumanising discourse regarding the enemy that was conceived in the rebel rearguard centred on the constant discrediting of the labour movement, Republican and even liberal ideologies. This discourse bestowed on all these ideologies disproportionate and debasing labels, attributing to them powerful and imaginary forces that conspired in a contemptible way against the Hispanicist essentialism firmly rooted in the traditions of Catholicism, patriotism, hierarchy and defence of the race. According to this viewpoint, the left-wing movements and democratic republicanism were the incarnation of the anti-Spain $^{10}$.

The revolution that broke out in the Republican rearguard during the early months of the conflict was worthy of close attention in the cultural construction of the discourse dehumanising and discrediting the left-wing. The popular revolution was presented as a horrendous phenomenon of moral degradation and of absolute loss of the values most purely cultivated by the spirit of Catholicism and Spanish nationalism. The Civil War became the inevitable historical event that was to return to the Spanish nation its ancestral greatness and spiritual purity, violently usurped by the most extreme manifestations of left-wing revolution ${ }^{11}$. The anti-leftist discourse conceived by the rebels contained at least some of the following elements.

Firstly, in almost all the literature linked to the events taking place in parts of the Republican rearguard, there is a distorted description of the socioeconomic transformations that were disturbing those areas. On many occasions it was concluded that the totality of those revolutionary changes meant, above all, an abominable and caricature-like imitation of Soviet communist forms of social organisation and expressions of centralised economic planning ${ }^{12}$.

Secondly, the left-wing's domination of "loyal" territories in the Republican rearguard meant a painful aggravation of the accelerated historical process of moral degradation and national ruin. The "red domination" of those territories which had not been quickly "liberated" exacerbated a whole series of perverted values and a range of anti-patriotic forms

\footnotetext{
${ }^{9}$ See 'La patriótica alocución del general Franco al iniciar el Movimiento (Tetuán, 21 de julio de 1936)', in $A B C$ de Sevilla, 23-7-1936; and Juan Ignacio Luca de Tena: 'Cara a la Nueva España', in ABC de Sevilla, 9-9-1936.

${ }^{10}$ See Ideal, "Contra quiénes luchamos", 5-8-1936. See also: "La contrarrevolución”, by Álvaro Alcalá Galiano, in $A B C$ de Sevilla.

${ }^{11}$ See: "La patriótica alocución del general Franco al iniciar el movimiento", in ABC de Sevilla, 23-7-1936.
} 
COBO ROMERO, Francisco, DEL ARCO BLANCO, Miguel Ángel y ORTEGA LÓPEZ, Teresa, "The Stability and Consolidation of the Francoist Regime. The case of Eastern Andalusia, 1936-50”, Contemporary European History, 20, 1, 2011, pp. 37-59.

of behaviour in the heart of local government bodies and municipal institutions. Such values and types of behaviour were found to be tinged with the meanness, avarice and materialism of their perpetrators, who were seen as responsible for the most profound degradations possible in social, spiritual and cultural life ${ }^{13}$.

Thirdly and lastly, the "frenzied anti-clericalism" that took place in practically all the population centres in the "loyal" rearguard, was considered to be one of the most prominent features of the degenerate and degraded character attributed to the left-wing and the "enemies of Spain". For the political languages and discourse that were being structured in "nationalist" Spain, the left-wing as a whole was exclusively responsible for the most varied enactments of iconoclasm, sacrophobia and immense and collective hate for the sacred, which spread like wildfire in the summer of 1936 . The anti-clerical violence must be understood as the sudden and spontaneous expression of a profound desire to cut to the roots the old, unjust and hierarchical order that had traditionally been supported by the Catholic Church and its representatives. For that very reason, on many occasions this expression occurred by means of a destructive and cathartic action, inspired by the mystical belief in the virtues of purifying fire and the salvation of death as necessary tools for building a new socio-moral order ${ }^{14}$. It had a greater effect as propaganda to blame the left-wing for the "atrocities" of "frenzied" anti-clericalism triggered in the towns in the "loyal" rearguard. In this way, these actions were presented as an unrestrained storm of anti-Catholic hate, which jeopardised the purest ancestral values upon which was constructed the Spanish essentialism found among a very large proportion of the population ${ }^{15}$.

\section{Civil War myths and the spiritualised exaltation of the Nation}

In the feverish and suffocating climate of destruction, terror and death that suddenly overtook the mass confrontation that began in 1936, there was also room for discursive constructions favourable to the deified exaltation of violence, the dehumanising satanisation

\footnotetext{
${ }^{12} A B C$ de Sevilla, "Viviendo cuarenta días de comunismo rojo en Palma del Río", 16-9-1936; Cf. Ideal: "El destino de España", 9-8-1936.

${ }^{13}$ Ideal, "En Montefrío se estableció el régimen soviético", 31-VII-1936; Cf. Odiel, 5-8-1936.

${ }^{14}$ Mary Vincent, "'The Keys of the Kingdom": Religious Violence in the Spanish Civil War, July-August 1936', in Chris Ealham and Michael Richards, eds., The Splintering of Spain. Cultural History and the Spanish Civil War, 1936-39 (Cambridge: Cambridge University Press, 2005), 68-89, see especially 76-80.
} 
COBO ROMERO, Francisco, DEL ARCO BLANCO, Miguel Ángel y ORTEGA LÓPEZ, Teresa, "The Stability and Consolidation of the Francoist Regime. The case of Eastern Andalusia, 1936-50", Contemporary European History, 20, 1, 2011, pp. 37-59.

of the enemy and the sacralisation of the regenerative potential of wars, following in the wake of the mythogenous and visionary politics of Fascism ${ }^{16}$. Once the war was over, that sublimated interpretation of the missionary character bestowed on the conflict allowed the victors to see themselves as belonging to a kind of mythical community, forged in ties of blood and the glorious and sacred fight for the Regeneration of the Fatherland ${ }^{17}$.

The symbolic foundations of the discourse created by "nationalist Spain" converted the combatants fighting the Second Republic regime into true champions of an epic with profound ethical dimensions, focussed on the complete extermination of Spain's enemies and on the establishment of the cultural, mystical and political bases on which the definitive "regeneration of the Hispanic race" would be erected ${ }^{18}$. What we shall call a "legitimising discourse" in terms of the conflict was based on the reuse of a vast amalgam of linguisticcultural elements, which were somehow present in a tradition of integrated, Catholic and reactionary nationalism with deep historical, ethical and political roots. In this regard, the stated discourse acted as a storehouse of the thought and intellectual tradition with antimodernist, reactionary, traditionalist, authoritarian and anti-liberal roots that had been evolving since the end of the $19^{\text {th }}$ and the beginning of the $20^{\text {th }}$ centuries ${ }^{19}$. This discourse was finally invaded by the intellectual and cultural currents of Fascism, radical nationalism, Catholic traditionalism and anti-parliamentarianism. The Fatherland was reclaimed once again by the divine will, letting it play the sacrosanct role of spiritual and universal disseminator of Catholicism which it had been playing since time immemorial ${ }^{20}$. The war was designated as a landmark of colossal dimensions and transformatory prospects, through which the purest roots of Hispanic essentialism ${ }^{21}$ had been called once again to a titanic task of

\footnotetext{
${ }^{15}$ See Ideal-Jaen Edition, 'Los vecinos de Arjona recuerdan aún con horror los crímenes cometidos durante el dominio rojo', 6-5-1939. Cf. ABC de Sevilla, "La columna del comandante Buiza toma Cazalla. El odio a la religión", 15-8-1936.

${ }^{16}$ George L. Mosse, Fallen Soldiers. Reshaping the Memory of the World Wars (New York: Oxford University Press, 1990), 159-81 and 'Toward a General Theory of Fascism', in George L. Mosse, Masses and Man. Nationalist and Fascist Perceptions of Reality (New York: Howard Fertig, 1980), 159-96, 170-4.

${ }^{17}$ See Sergio Luzzatto, 'The Political Culture of Fascist Italy', Contemporary European History, 8, 2, 1999, $317-$ 34, 322-4; James A. Gregor, Mussolini's Intellectuals. Fascist Social and Political Thought (Princeton, Princeton University Press, 2006), 78-84.

${ }^{18}$ See Ideal, 'Luces y resplandores de la Guerra', 4-10-1936; ABC de Sevilla, 'Discurso del Generalísimo Franco ante el micrófono de Radio Nacional', 20-7-1937; and Antonio Gallego y Burín, Seis discursos y una conferencia (Granada: Talleres Tipográficos A. Márquez, 1937), 23-37.

${ }^{19}$ Pedro Cerezo Galán, El mal del siglo. El conflicto entre Ilustración y Romanticismo en la crisis finisecular del siglo XIX (Madrid: Biblioteca Nueva and Universidad de Granada, 2003), 633-42.

${ }^{20}$ Eduardo González Calleja and Fredes Limón Nevado, La Hispanidad como instrumento de combate. Raza e imperio en la prensa franquista durante la Guerra Civil española (Madrid: CSIC, 1988), 31-45.

${ }^{21}$ See 'El Frente Nacional', by Francisco de Cossío, ABC de Sevilla, 11 September 1936.
} 
COBO ROMERO, Francisco, DEL ARCO BLANCO, Miguel Ángel y ORTEGA LÓPEZ, Teresa, "The Stability and Consolidation of the Francoist Regime. The case of Eastern Andalusia, 1936-50", Contemporary European History, 20, 1, 2011, pp. 37-59.

ethical, mental and mystical regeneration ${ }^{22}$. To this must be added the vast process of creating a discourse full of symbolic components, confined to a powerful imaginary exalting the Eternal Nation, and installed on a mythified and allegorical paraphrasis. This paraphrasis, incorporating numerous Fascist components ${ }^{23}$ and which had millenarian and messianic features ${ }^{24}$-some of them taken from traditional Catholic doctrine ${ }^{25}$-, perceived the timeless existence of a Fatherland immersed in a permanent cycle that reproduced the stages of Paradise, Fall and Redemption ${ }^{26}$. What the propagandists and ideologists of the nascent Francoist Spain did was nothing other than recover the discourses, philosophical traditions and political cultures of neo-Hegelian idealism, essentialist nationalism ${ }^{27}$, Fascism and antiparliamentarian authoritarianism. Many of those components were found to be available in the European anti-liberal intellectual storehouse ${ }^{28}$.

One contribution to the discourse was reasoning typical of populist ultra-nationalism and Fascism. The call was for the regenerative rejuvenation of the Nation and its erection on a new political order that would overcome liberalism ${ }^{29}$. It is worth highlighting the symbolism used when unravelling the historical roots that had led to the outbreak of the Civil War. It was stated that the Spanish Nation had, in recent decades, been immersed in an irreversible process of decline. What was being evoked, then, was the simile of the infirm Nation, threatened (or assaulted) by an (internal or external) enemy, or by a multifarious range of

\footnotetext{
${ }^{22}$ See in this regard: 'Cara a la Nueva España', by Juan Ignacio Luca de Tena, in $A B C$ de Sevilla, 9 September 1936; and ABC de Sevilla, 'Discurso pronunciado por Pedro Sainz Rodríguez (Vicepresidente), en el transcurso del acto de Constitución del Instituto de España, celebrado en el Paraninfo de la Universidad de Salamanca, el 6 de enero de 1938', 7 January 1938.

${ }^{23}$ Cf. Aristotle A. Kallis, 'To Expand or Not to Expand? Territory, Generic Fascism and the Quest for an "Ideal Fatherland", Journal of Contemporary History, 38, 2 (2003), 244-6.

${ }^{24}$ See: Emilio Gentile, Politics as Religion (Princeton: Princeton University Press, 2006), 141-2; Box, 'La tesis de la religión política', 223-4; Richard Steigmann-Gall, El Reich sagrado. Concepciones nazis sobre el cristianismo, 1919-1945 (Madrid: Akal, 2007), 27-70; and, by the same author: 'Apostasy or religiosity? The cultural meanings of the Protestant vote for Hitler', Social History, 25, 3 (2000), 279-84; see also John F. Pollard, “'Clerical Fascism": Context, Overview and Conclusion', Totalitarian Movements and Political Religions, 8, 2 (2007), 434-7.

${ }^{25}$ Isidro Gomá y Tomás, 'Carta Pastoral sobre el sentido cristiano-español de la Guerra', in Pastorales de la Guerra de España (Madrid: Rialp, Rivadeneyra, 1955).

${ }^{26}$ See Box, 'Secularizando el Apocalipsis', 151-2. See Manuel García Morente, Idea de la Hispanidad (Madrid: Espasa-Calpe, 1961), 15-22; and by the same author: 'Ideas para una Filosofía de la Historia de España', in Idea de la Hispanidad, 179-209 and 'Raíces históricas del movimiento nacionalista', in Obras Completas, vol. II, 1937-1942, (Barcelona: Anthropos, 1996), 377-82.

${ }^{27}$ See Manuel García Morente, 'España como estilo', in Idea de la Hispanidad, 34-45.

${ }^{28}$ See Pedro Carlos González Cuevas, 'La inflexión autoritaria del liberalismo español', in Manuel Suárez Cortina, ed., Las máscaras de la libertad. El liberalismo español, 1808-1950 (Madrid: Marcial Pons, 2003), 4349 and 446-9. Consult Ismael Saz, España contra España, 82-6.
} 
COBO ROMERO, Francisco, DEL ARCO BLANCO, Miguel Ángel y ORTEGA LÓPEZ, Teresa, "The Stability and Consolidation of the Francoist Regime. The case of Eastern Andalusia, 1936-50", Contemporary European History, 20, 1, 2011, pp. 37-59.

invasive and harmful agents that would besiege its unity and strength. To confront this process of debilitation, there was a call to eradicate the infiltrating agents (Marxism, atheism, Judaism, freemasonry, anti-clericalism, separatism, the regions' nationalist or "anti-Spanish" feeling and even Soviet communism), and elements besieging the racial essences on which the Nation's spiritual purity was based ${ }^{30}$. For all these reasons, both the military uprising against the Republic and the Civil War itself became phenomena interpreted as a memorable immolation in a group sacrifice imposed by God and installed upon an eschatological and sanctifying shedding of blood and death ${ }^{31}$.

The war, then, was presented as the collective historical endeavour to return to the Fatherland its damaged Catholic and traditionalist essentialism. Victory over the enemy, achieved by means of the sacrifice provided by blood and death, was interpreted as an event saturated with mystical, millenarian and regenerative energies ${ }^{32}$. The conflict was the crucible from which a New Spain would emerge, born from the abolition of the decrepit liberalparliamentarian construction, and refounded and resuscitated thanks to the fusion of energies arising from its most noble and ancestral ideals ${ }^{33}$. The liberation movement and the violent response to the enemy became an enterprise that would necessarily be sustained by a heterogeneous set of social and professional groups, united in the defence of their common anti-leftist, anti-democratic feeling and their desire for national regeneration ${ }^{34}$.

\footnotetext{
${ }^{29}$ Roger Griffin, 'Il nucleo palingenetico dell'ideologia del "fascismo generico", in Alessandro Campi, ed., Che cos'é il fascismo? (Rome: Ideazione Editrice, 2003), 97-122. See also Roger Griffin, ed., International fascism: theories, causes and the new consensus (London \& New York: Arnold, Oxford University Press, 1998).

${ }^{30}$ Isidro Gomá y Tomás, El Caso de España. Instrucción a sus diocesanos y respuestas a unas preguntas sobre la guerra actual (Pamplona: Diputación Foral de Navarra, 1936), 20-1.

31 Isidro Gomá y Tomás, "La Cuaresma de España. Carta Pastoral sobre el sentido cristiano-español de la guerra”, en Gomá y Tomás, Isidro, Por Dios y por España, (Barcelona, Rafael Casulleras, Librero, 1940), pp. 87-127.

${ }^{32}$ See Ideal, 'Luces y resplandores de la Guerra', 4 October 1936. See also ABC de Sevilla, 'Discurso del Generalísimo Franco ante el micrófono de Radio Nacional', 20 July 1937; Ideal, 'Granada celebra con esplendor el Día del Alzamiento. Discurso del Sr. Gallego Burín', 19 July 1938, and Ideal, 'La Bandera de la Victoria', 15 August 1936. Regarding the 'mythic core' of 'generic fascism', as well as the mythified idealisation of 'national decadence' and the mythogenous and regenerative component of its revolutionary and anti-democratic discourse, consult Roger Griffin, The Nature of Fascism (London \& New York, Routledge, 1993), 26-43, and more recently Roger Griffin, 'The Primacy of Culture: the Current Growth (or Manufacture) of Consensus within Fascist Studies', Journal of Contemporary History, 37, 1 (2002), 37-43.

${ }^{33}$ Ideal, 'Luces y resplandores de la Guerra', 4 October 1936, and 'La bandera de la victoria', 15 August 1936.

${ }^{34}$ Ideal, 'Santiago y ¡Viva España!', 26 July 1936 and 'Contra quiénes luchamos', 5 August 1936.
} 
COBO ROMERO, Francisco, DEL ARCO BLANCO, Miguel Ángel y ORTEGA LÓPEZ, Teresa, "The Stability and Consolidation of the Francoist Regime. The case of Eastern Andalusia, 1936-50”, Contemporary European History, 20, 1, 2011, pp. 37-59.

\section{The "culture of victory"}

The Civil War changed everything. As we have pointed out, it would be seen as a providential, mythical and regenerative event. The "Crusade" was understood as the decisive moment when Spain would be reborn from its ashes, becoming once again what it had been, purified by the blood of true Spaniards. After 1 April 1939, the war would not be forgotten, but would become a focus for the propaganda and politics of Francoist memory, legitimising the regime's existence and its decisions. ${ }^{35}$ In this way, a "culture of war" would spread that considered the fight to be unfinished, at least implicitly, and that Spain should complete its resurgence by purging its weakened body by means of sacrifice and isolation. Furthermore, this is where the adoption of an autarchical economic, cultural and political programme would fit in. An interventionist policy was implemented by which the country renounced all imports and any international contact, it closed the doors on pernicious external economic and cultural influences and looked inwards; after all, its borders contained not only all the economic and natural resources that would allow the nation to become great, but also all the "spiritual resources" that had once made it an empire. ${ }^{36}$

Spain had to return to its roots, to the "eternal essence" that had once made it great. It had to close in on itself, looking to the countryside, "Spain's eternal breeding ground".37 Responding to its agrarian social origins, the "New State" filled its discourses and proclamations with extensive references to the Spanish countryside, praising its virtues and the peasants who lived there. ${ }^{38}$ The countryside and especially the lands of Castile were identified as all that was truly Spanish, with the purity, Christian faith and courage that characterised the Hispanic race. This was the salvation when confronted with the cities, those sites of Republican evil, dens of Marxism, liberalism, atheism and anarchy. As a result, an agrarian policy was imposed in order to guarantee that the urban evils would be cleansed, nourishing "the Spanish resurgence with sap". This would be the explanation for the extreme protection of and intervention in prices and production in the forties: it was nothing more than

\footnotetext{
${ }^{35}$ Paloma Aguilar, Memoria y olvido de la Guerra Civil española (Madrid: Alianza, 1996), 57.

${ }^{36}$ Michael Richards, A Time of Silence. Civil War and the Culture of Repression in Franco's Spain, 1936-1945 (Cambridge: Cambridge University Press, 1998); Michael Richards, 'From War Culture to Civil Society. Francoism, Social Change and Memories of the Spanish Civil War', History and Memory, 22 (2002), 93-120.

${ }^{37}$ Point 17 of the Unificación de Partidos (Unification of Parties) Decree, 19 April 1937, Boletín Oficial del Estado, 20 April 1937.
} 
COBO ROMERO, Francisco, DEL ARCO BLANCO, Miguel Ángel y ORTEGA LÓPEZ, Teresa, "The Stability and Consolidation of the Francoist Regime. The case of Eastern Andalusia, 1936-50”, Contemporary European History, 20, 1, 2011, pp. 37-59.

a way of halting the city's profit-making and setting a limit on the hidden interests of private capital. $^{39}$

In everyday life after the war, the "New State" would keep alive the spirit of the Civil War, bringing about a true "culture of victory". However, this would not be a culture merely imposed "from above." After all, it is in the local sphere that it was received, and indeed formed, allowing Francoism's followers to participate in its constitution and feel part of that "community of victors."

The symbols and rites that would constitute Francoism's official culture had already appeared during the conflict; over the course of the forties, they would come to dominate everyday life. ${ }^{40}$ These highlighted the existence of an exclusive national community, emotionally linked to the postulates of national regeneration, the rejection of the past democratic-Republican experience and the exaltation of traditional Catholic values. This became evident, for example, in the ritualised celebrations and commemorations of the rebel military victories during the Civil War, where the political combined with the religious. For example, the recollections of the military uprising against the Second Republic regime, held in 1937, 1938 and 1939 throughout the Andalusian rebel rearguard, turned into episodes of fervent communion, exalting a new era and a new state. ${ }^{41}$ The Falangist militias' street parades were attended by crowds of people who professed their religious faith and nationalist ardour. At all of them, the sacralised forms of the Catholic cult united with the symbols of a new secular religion that joyfully worshipped the Liberated Nation and blessed the providential return of the One Fatherland's imperial and Catholic splendour. ${ }^{42}$ At many of these expressions of unconditional adhesion to the incipient Francoist state's principles, the populace participated in a sort of celebration loaded with aesthetic, liturgical, mystical and almost sacred components.

\footnotetext{
${ }^{38}$ Example: Federico de Urrutia, ‘'Arriba el campo!', in Poemas de la Falange Eterna (Editora Nacional, 1938), 46-9. Also: Eduardo Sevilla Guzmán, La evolución del campesinado en España (Barcelona: Península, 1979), 143-53.

${ }^{39}$ Evidence for this can be found in some of Francisco Franco's statements in those years: 'Vivir cara al campo', 27 May 1950; and 'Castilla, vivero de España', 2 March 1950, in Textos de doctrina política. Palabras y escritos de 1945 a 1950 (Madrid: Publicaciones Españolas, 1951), 507 and 185.

${ }^{40}$ Rafael Cruz, 'Old symbols, new meanings: mobilising the rebellion in the summer of 1936', Chris Ealham and Michael Richards, The Splintering, 159-76.

${ }^{41}$ Cf. Julián Casanova, La Iglesia de Franco, Barcelona, Crítica, 2005, 72-4. See also Giuliana di Febo, Ritos de guerra y de victoria en la España franquista, Bilbao, Desclée de Brouwer, 2002, 154-5.

42 On 18 July 1937, well-attended civic-military-religious events were held in the largest towns and cities of Nationalist Andalusia; almost all of them were the scene for a common pattern of commemorative events that attracted crowds of people. Cf. ABC de Sevilla, "Toda la España Liberada por el heroico esfuerzo del Ejército celebra con brillantes actos la fecha 18 de julio", 20-8-1937.
} 
COBO ROMERO, Francisco, DEL ARCO BLANCO, Miguel Ángel y ORTEGA LÓPEZ, Teresa, "The Stability and Consolidation of the Francoist Regime. The case of Eastern Andalusia, 1936-50", Contemporary European History, 20, 1, 2011, pp. 37-59.

From this point of view, it is easier to understand the vigorous drama of the so-called "campaign mass." These masses were set in open public spaces, dominated by monumental stages showing insignias and emblems alluding to the fusion between "the cross and the sword" and given a moving sensory and emotive theatricality. This is, at least, what can be gathered from the many bombastic celebrations of the " $3{ }^{\text {rd }}$ Triumphal Year" held on 18 July 1938 both in the city of Seville ${ }^{43}$ and in the main population centres and provincial capitals of "nationalist" Andalusia. ${ }^{44}$ The culmination was the ostentatious commemoration of the rebel army's victory in the Civil War that took place in Seville on 17 April 1939 in the presence of Generalisimo Franco and General Queipo de Llano, with around 60,000 uniformed men and more than 300,000 people attending. ${ }^{45}$

The symbols that made up the "culture of victory" were also forged at these events. These would provide a communication channel by which the population would express their adhesion to the "New State", while participating in its symbolic construction. Thus, the monarchical flag was adopted as the national flag and raised over official buildings after a place was conquered. On 15 August 1936, in the city of Granada, the population participated in a ceremony at the Cathedral: the 'fervent crowd' went there to salute the flag solemnly to the sound of applause and shouts of "Viva España". The flag was also used in other important ceremonies. In the village of Cogollos (Granada), the bereaved used it to cover the coffins of their "martyrs" during the Civil War, while the villagers saluted with the Roman salute during the funeral. ${ }^{47}$ In later years, the flag presided over official, popular and religious festivals, adorning the streets and squares of towns and cities. Many of their inhabitants would hang it from their balconies and windows, bearing witness to their support -or perhaps fearof the Francoist regime and making it part of the day-to-day scenery in those years.

The war meant the return of the national anthem (Marcha de Granaderos), as well as the use of other, secondary anthems (the Falangist Cara al Sol, the Carlist Oriamendi, the Spanish Legion's anthem, etc. ${ }^{48}$. These were insistently present at official ceremonies, processions and religious events, showing that the "true Spain" was inseparable from the

\footnotetext{
${ }^{43}$ Cf. Concha Langa Nuño, Educación y propaganda en la Sevilla de la Guerra Civil, Seville, Biblioteca de Temas Sevillanos, 2001, 51-2.

${ }^{44}$ Cf. $A B C$ de Sevilla, "España, redimida por Franco, vibró ayer de fervores patrióticos al conmemorar el 18 de julio", 19-71938. Ideal, "Granada celebra con gran esplendor el Día del Alzamiento", 19-7-1938 and Cándido Ortiz de Villanos, Crónica de Granada en 1938; II-III Año Triunfal, Granada, Imprenta Urania, 1938, 145-6.

${ }^{45}$ Cf. Ideal, "Unas trescientas mil almas en plena exaltación patriótica", 18-4-1939.

${ }^{46}$ Claudio Hernández Burgos, La construcción de la Cultura de la Victoria en Granada, 1936-1951, Memoria de Licenciatura Inédita, (Granada: Universidad de Granada, 2009), 104.

${ }^{47}$ Ideal, "Numeroso público asistió al entierro de los falangistas muertos heroicamente en Cogollos", 26-1-1937.

${ }^{48}$ A good example of this variety and of its meaning for one of the regime's ideologists in: Ernesto Giménez Caballero, La infantería española (Madrid: Ediciones de la Vicesecretaría de Educación Popular, 1941), 67-79.
} 
COBO ROMERO, Francisco, DEL ARCO BLANCO, Miguel Ángel y ORTEGA LÓPEZ, Teresa, "The Stability and Consolidation of the Francoist Regime. The case of Eastern Andalusia, 1936-50”, Contemporary European History, 20, 1, 2011, pp. 37-59.

Catholic religion. In Granada, for instance, a local newspaper stated "the populace stand and sing [all the anthems] together, with the same enthusiasm, because all sing to the great, noble, just and strong Fatherland, to which they have consecrated their effort and their lives." ${ }^{, 9}$ The use of war anthems was extended into the "years of peace", paying homage to the martyrs of the "Crusade" in their lyrics and indicating that those who remained alive and in charge of the institutions were continuing to combat the enemy, lining up with their fallen companions, who stood "guardia sobre los luceros" ("guard over the stars"). 50

It was necessary to recover Catholicism and its Baroque and counter-Reformation spirit, the traces of the true Hispanic tradition and elements that could purify the "Fatherland's sins". ${ }^{51}$ Already during the war, acts of desagravio (amends or reparation) took place and masses were held at the front and in the rearguard; processions and pilgrimages occurred and, of course, crucifixes were returned to schools and public buildings. Religion and God, identified with Nationalist Spain, were returned to their place, making them present in everyday life during the post-war period. Not even condemned Republicans could escape these symbols: in January 1937, an event was held to replace the crucifix in Granada Prison, with a number of political prisoners lined up in the courtyard to listen to the head of the institution's triumphalist speech. ${ }^{52}$ In towns and cities, masses set the rhythms of daily life: attending Sunday mass became an act of support for the regime and, for some, a way of avoiding reprisals or being marked politically. Parish priests and clergymen became judges of the moral, religious and political conduct of the parishioners. ${ }^{53}$ With the notion that Spain's "purification" was only possible through penitence, a great many religious celebrations were held during the war and postwar period at which the political and the religious went hand in hand. These became acts in which the population participated, showing their Christian faith and patriotism. All these manifestations fitted in with the desire expressed by both the Catholic Church and the Francoist "New State" to remove the deep roots of secularism and atheist materialism fostered by the Second Republic. In this way, Spanish society was reCatholicised, occupying public spaces in towns and cities, while Francoism's supporters were offered an opportunity to participate and show their adhesion and belonging to this "culture of victory". These supporters used gestures to combine the religious and the political in ways

\footnotetext{
${ }^{49}$ Ideal, 17-9-1936.

50 'Cara al Sol', Anthem of the Falange Española Tradicionalista y de las JONS.

${ }^{51}$ Giuliana Di Febo, Ritos de guerra y de victoria en la España franquista (Bilbao: DDB, 2002), 27-38.

${ }^{52}$ Ideal, 19 January 1937.

${ }^{53}$ Conxita Mir, Vivir es sobrevivir. Justicia, orden y marginación en la Cataluña rural de posguerra (Lleida, Milenio, 2000), 189-237; Ramón García Piñeiro, 'Boina, bonete y tricornio. Instrumentos de control campesino en la Asturias franquista (1937-1977)', Historia del Presente, 3 (2004), 45-64.
} 
COBO ROMERO, Francisco, DEL ARCO BLANCO, Miguel Ángel y ORTEGA LÓPEZ, Teresa, "The Stability and Consolidation of the Francoist Regime. The case of Eastern Andalusia, 1936-50", Contemporary European History, 20, 1, 2011, pp. 37-59.

that reflected the identification between the two lying at the very heart of the crusade. ${ }^{54}$ Particularly noteworthy are the missionary campaigns carried out in remote rural areas, the dramatised mass missions in large population centres and the group celebrations of christenings or Catholic weddings held to make amends for the damage suffered by the Church due to the application of the Republican period's secular and anti-religious legislation. Most of these ritualised representations intended to stage the return of the values and beliefs of that traditional, essentialist and anti-modern religiosity upon which large parts of the middle classes and the oligarchies had been building their particular status. Of this frenzied anxiousness to re-Catholicise, an important element was the consecration of many towns and cities to the Sacred Heart of Jesus, with a clearly expiatory aim. Some of these consecrations became tremendous manifestations of the crowd's Catholic fervour, as shown by the fact that, in June 1945, the town of Guadix (Granada province) took in an impressive throng of 50,000 people who crowded around the cathedral, which was crowned by a majestic image of Christ. $^{55}$

However, the most intense public liturgies were certainly the ones that formed a glorious climax to the re-Catholicisation of the 1940s, the two Great Popular Missions held in the cities of Jaen and Granada. The Holy Mission in Jaen took place between 18 February and 9 March 1947. This involved the participation of a total of 26 Redemptorist missionaries and members of the order of the Immaculate Heart of Mary, presided over by Bishop García y García de Castro. During the event, the priests, distributed in numerous places of worship, preached to the different guilds, trades and corporations of the city, to representatives of the Chamber of Commerce and Industry and to workers in general (bricklayers, carpenters, railway workers, peasants, mechanics, etc.). The Holy Mission ended with two grand, crowded events: the Stations of the Cross on 26 February that came out in the Plaza de Santa María, in front of the cathedral, ending with a huge gathering of more than 40,000 of the faithful; and the concluding masses held on Sunday 2 March, at which more than 15,000 communions were given. ${ }^{56}$

The Holy Mission in Granada took place from the 16 to 30 October 1949, and during the event 103 missionaries from all over Spain took part. Both daytime and night-time religious events were held in all of the city's churches and improvised spaces, and conferences intended for all sections of society were run. So that the "missionary's voice would reach to the last house and the most remote and secluded corner," the majority of the churches and religious buildings were installed with exterior loudspeakers: and even the busiest streets and squares of

\footnotetext{
${ }^{54}$ Mary Vincent, 'Expiation as Performative Rhetoric in National-Catholicism: The Politics of Gesture in PostCivil War Spain', Past and Present, 203 (2009), 240.

${ }^{55}$ Cf. Claudio Hernández Burgos, La construcción de la Cultura, 149-50 and Patria, 6 June 1945.

${ }^{56}$ Cf. Boletín Oficial Eclesiástico del Obispado de Jaén, Marzo de 1947; Ideal, Edición Jaén, 12-2-1947 and 43-1947.
} 
COBO ROMERO, Francisco, DEL ARCO BLANCO, Miguel Ángel y ORTEGA LÓPEZ, Teresa, "The Stability and Consolidation of the Francoist Regime. The case of Eastern Andalusia, 1936-50”, Contemporary European History, 20, 1, 2011, pp. 37-59.

the city centre (Puerta Real, el Embovedado, Plaza del Campillo, Plaza de la Mariana, Plaza Bib-Rambla, Calle San Matías and Calle Navas) were provided with giant loudspeakers, broadcasting the speeches that Archbishop Balbino Santos y Olivera was giving on Radio Granada. At the end of each day, a general gathering of missionaries and parishioners took place in el Embovedado, an iconic location where an altar with a foliage cross, five metres high and two metres wide, was erected. After two weeks of hectic liturgical activity, the triumphant balance sheet drawn up by the Granadan church documenting the scope of the "Great Mission" was the following: attendance of children: 2,000; attendance of adults: 40,000 to 50,000; average attendance at each of the general gatherings: 70,000 to 80,000 of the faithful; communions given during the mission: 120,000; overall number of people participating in the mission: 85,000 ; illicit matrimonial unions canonised: $544 .^{57}$

These devotional and patriotic ceremonies were directly related to memories of the Civil War. For this reason, the regime took care to occupy the spaces with symbols and rites closely linked to memory of the conflict. The Civil War occupied the streets and squares: the changing of names began very early on, erasing any trace of the Republican period and putting in place new myths and heroes of the "anti-Spain's" defeat. For example, in February 1937, shortly after taking the city of Malaga, the Francoist authorities announced that names would be substituted, removing indications of those "men who were revolting because of the poison of their ideas; because of the cruelty and ferocity of their instincts; because of the ruin they brought upon our Fatherland", in this way cleansing any trace, even the names, of this "false Spain". 58

Remembrance of the war's martyrs and heroes became a central element of the postwar liturgy. These men would be the ideal models for the new regime: an example of masculinity, courage, heroism, purity, faith and sacrifice. They had fertilised the future of the "New Spain" with their blood. ${ }^{59}$ They should not be forgotten and they were to be present in the victors' imaginary. A good example of this is their presence in the public sphere, with their names being given to the new streets and roads of the resurgent Fatherland. Now, victors and vanquished would live in and travel through streets with the names of the victors. This was not merely the case for exalted and far-off names like José Antonio Primo de Rivera or

\footnotetext{
57 Cf. Crónica de la Santa Misión General de Granada, Boletín Oficial Eclesiástico del Arzobispado de Granada, Número Extraordinario, January 1950, 111-2.

${ }^{58}$ Archivo General de la Administración (AGA), Ministerio del Interior. Box 3910, 20-2-1937.

${ }^{59}$ Mary Vincent, 'The Martyrs and the Saints: masculinity and the construction of the Francoist Crusade', History Workshop Journal, 44 (1999), 68-98.
} 
COBO ROMERO, Francisco, DEL ARCO BLANCO, Miguel Ángel y ORTEGA LÓPEZ, Teresa, "The Stability and Consolidation of the Francoist Regime. The case of Eastern Andalusia, 1936-50”, Contemporary European History, 20, 1, 2011, pp. 37-59.

Francisco Franco, but also provincial and even local heroes. In the town of Santa Fe (Granada province), next to a street bearing the name of José Antonio we find others with the names of the two soldiers who led the coup in the nearby provincial capital, and two more streets dedicated to inhabitants of the town itself. ${ }^{60}$ The Civil War and its memory "made equal" those who fought and gave their blood for Spain, perpetuating their memory and binding the community of the victorious.

Crosses were erected in honour of the fallen in every town and city. They occupied the most important places, bearing the names of those who had "fallen for God and Spain". The crosses linked past, present and future: they placed the living and the dead on the same temporal plane; like other European nations during the interwar period, the nation was not only made up of those alive at that time, but also previous generations, those who had died, and future generations, those who were yet to come and who were to ensure the eternity of the "Fatherland". ${ }^{61}$ On many occasions, their construction was promoted by those who identified themselves with the victorious group and by those who spontaneously undertook popular subscriptions to honour the memory of their relatives. ${ }^{62}$ The crosses to the fallen dominated local life, occupying the main streets or squares. One example is that of Montefrío (Granada province), whose council agreed in 1943 to raise theirs on the hill overlooking the place, so that it could be "visible from everywhere in the town". ${ }^{63}$ The reminder of the Civil War cast its shadow over the lives of all the residents.

On a great many occasions, their inauguration became an act of desagravio and support. For example, the inauguration of the Cross for the Fallen in Alcalá la Real (Jaen province) in 1941 was preceded by a mass-funeral in the important abbey church of Santa María la Mayor. This was attended by the town's "living forces", relatives of martyrs, excombatants, those persecuted or imprisoned by the Republican authorities and all fervent supporters of Francoism: the "community of victory". After the service, carried out by the vicar-general of the diocese, all those present filed out and met before the monument; here

\footnotetext{
${ }^{60}$ Archivo Histórico Municipal de Santa Fe (AHMSF), 273 Libro de Actas of the Comisión Gestora, 17-4-1937, 14 April 1937 and 31 March 1937.

${ }^{61}$ George L. Mosse, Fallen Soldiers, 49.

62 José Luis Ledesma Vera and Javier Rodrigo, 'Caídos por España, mártires de la libertad: víctimas y conmemoración de la Guerra Civil en la España postbélica (1936-2006)', Ayer, 63 (2006), 244.

${ }^{63}$ Example: Archivo Histórico Municipal de Montefrío (AHMM), Libro de Actas of the Ayuntamiento of Montefrío (1941-1945), Comisión Gestora 10 April 1943.
} 
COBO ROMERO, Francisco, DEL ARCO BLANCO, Miguel Ángel y ORTEGA LÓPEZ, Teresa, "The Stability and Consolidation of the Francoist Regime. The case of Eastern Andalusia, 1936-50”, Contemporary European History, 20, 1, 2011, pp. 37-59.

there were speeches, flags were raised, anthems were sung and the spirit of the "Crusade" was revived once again. ${ }^{64}$

Like other interwar Fascist regimes, Francoism reordered time to legitimise and perpetuate itself. ${ }^{65}$ Even here, the long shadow of the Civil War was extended, with the reorganisation of the calendar to perpetuate and celebrate remembrance of the conflict. It would be impossible to escape reminders of the victory, those meanings that distilled the victors' shared culture in each discourse, ceremony and newspaper item. Popular and secular festivals were abolished. Religious festivals and ones linked to the Francoist regime were imposed: National Catholicism was established in the public sphere, creating a space for and transmitting its ideology ... but it also penetrated into the private sphere, into families and into individuals' faith, beliefs and morals. ${ }^{66}$

Political and religious commemorations suffocated the lives of Spaniards: the anniversary of the Glorious National Uprising, "Victory" day, the death of El Ausente (the Absent One), the Caudillo's saint's day, commemoration of St Theresa ... In parallel to this, local religious festivals were spectacularly revitalised. All these involved the remembrance of those who had died in the conflict as well as the attacks on ecclesiastical images during the Republican period and the Civil War. As in Christian tradition, it had been necessary to sacrifice some of their sons to save Spain and ensure a new order. In Malaga, for example, these religious manifestations were presented as a way of purifying the streets, the bodies and the minds of Spaniards. In this way, the myths and the spirit of the Civil War were perpetuated, making them part of the language, memory and symbology of post-war Spain, perpetuating the division into victors and vanquished. ${ }^{67}$

The nineteen-forties were marked by this "culture of victory", exemplified by rites, symbols, festivals and celebrations. Like Fascist Italy, the rites became integral elements of society, which, participating in their representation and in their confirmation, felt identified with the regime that carried them out. ${ }^{68}$ In fact, these "victory rites" gave shape to an

\footnotetext{
${ }^{64}$ Diario Jaén, 'Inauguración del monumento a los caídos en Alcalá la Real', 16 September 1941.

${ }^{65}$ Martin Sabrow, 'Time and Legitimacy: Comparative Reflections on the Sense of Time in the Two German Dictatorships', Totalitarian Movements and Political Religions, 6, 3 (2005), 351-69.

${ }^{66}$ Ángela Cenarro, 'Los días de la "Nueva España": entre la "Revolución Nacional" y el peso de la tradición', Ayer, 51 (2003), 115-34. An example for the city of Valencia: Gil Manuel Hernández i Martí, 'Nacionalcatolicismo y calendario festivo en Valencia', in Javier Tusell, Susana Sueiro, José María Marín y Marina Casanova, eds., El régimen de Franco (1936-1975) (Madrid: UNED, 1993), 531-41.

${ }^{67}$ Michael Richards, 'Presenting arms to the Blessed Sacrament: civil war and Semana Santa in the city of Málaga, 1936-1939', Chris Ealham and Michael Richards, The Splintering, 221-2,

${ }^{68}$ Emilio Gentile, Il culto del Littorio (Roma-Bari, Laterza, 2003), 82-4.
} 
COBO ROMERO, Francisco, DEL ARCO BLANCO, Miguel Ángel y ORTEGA LÓPEZ, Teresa, "The Stability and Consolidation of the Francoist Regime. The case of Eastern Andalusia, 1936-50", Contemporary European History, 20, 1, 2011, pp. 37-59.

integrated community of victors that was separate from those who had lost the war. ${ }^{69}$ The "New State's" various forces and social supports were present at these ceremonies, thus creating an imagined community identified as the "true Spain", which awaited "justice" against the abominable Republican enemies, contaminated beings who were remote from God and pernicious to the Fatherland's health and future.

\section{The time of "Justice": repression and destruction of the enemy}

The thick sediment of cultural, allegorical, liturgical and discursive components that we have set out conferred stability on the Francoist regime. However, its importance does not only reside in this, but also in its interaction with society, as well as its spread and consequences over time. It was to be a liquid layer, overlapping with and giving meaning to the other two areas that allowed the "New State" to survive: repression and socioeconomic interests. Some towns in Eastern Andalusian offer us a perfect framework for observing this interaction, revealing the links between culture and reality, but also between local and national politics.

We cannot understand Francoism without repression, a true pillar of the "New State". ${ }^{70}$ The machinery of terror and annihilation was essential for the paralysis and elimination of possible opponents: extra-judicial killings, military trials, the Ley de Responsabilidades Políticas (Political Responsibilities Law), exile, prison, concentration camps... The violence was so brutal that in 1999 a study estimated that Francoist repression, including the Civil War and post-war periods, claimed a startling 150,000 victims. Even today new local studies are appearing, increasing this figure and rescuing the names of those who disappeared. ${ }^{71}$

In interwar authoritarian regimes, repression and violence were not simply imposed from above: in Nazi Germany, the civil population played an active role in the tasks of policing, control and repression, participating and collaborating "from below" by means of

\footnotetext{
${ }^{69}$ Pedro Payá, 'Violencia, legitimidad y poder local. La construcción simbólica de la dictadura franquista en una comarca alicantina. El Vinalopó medio, 1939-1948', Pasado y Memoria, 1 (2002), 197-222.

70 Ángela Cenarro, 'Muerte y subordinación en la España franquista: el imperio de la violencia como base del "Nuevo Estado"”, Historia Social, 30 (1998), 5-22.

${ }^{71}$ Santos Juliá, ed., Víctimas de la Guerra Civil (Madrid: Temas de Hoy, 1999), 410. Javier Rodrigo, Hasta la raíz. Violencia durante la Guerra Civil y la dictadura franquista (Madrid: Alianza, 2008).
} 
COBO ROMERO, Francisco, DEL ARCO BLANCO, Miguel Ángel y ORTEGA LÓPEZ, Teresa, "The Stability and Consolidation of the Francoist Regime. The case of Eastern Andalusia, 1936-50", Contemporary European History, 20, 1, 2011, pp. 37-59.

denunciations, reports and testimony. ${ }^{72}$ In the Spanish case, recent studies have shown the decisive and enthusiastic participation of the population in the annihilation and punishment of the Republicans. By analysing military trials in the Andalusian district of Los Pedroches, Peter Anderson has shown that on 70 percent of occasions the proceedings began on the initiative of members of civil society who, keen to obtain "Franco's justice" and fair retribution for the death of family members, were quick to denounce their neighbours. Their denunciations and statements show a view of the Republican enemy as monstrous and unnatural, the Civil War as a unique event and the punishment and annihilation of the vanquished as the reward expected from Franco's regime. ${ }^{73}$

The application of the Ley de Responsabilidades Políticas created similar tendencies. As is known, this measure went beyond the mere physical punishment of the vanquished: as well as imposing death penalties and prison sentences, the courts decreed the confiscation of the accused's property, in this way making the future difficult for that person's family. ${ }^{74}$ With the head of the family dead or in prison and his property confiscated, his family members would be plunged into poverty, another corridor in Francoism's maze of repression. In fact, the highest authorities in Andalusian towns did not hesitate to publish reports regarding the political activities and ideas of the accused, making use of residents' collaborative efforts to this end. Mayors, local Falange heads, Civil Guard officers, parish priests and even military commanders wrote an enormous number of reports, filling them with the official language and values which presented the Republican enemy as a subhuman, cruel and barbarous being. For example, in the file of the Socialist day labourer José María Arco Soto, of Montefrío (Granada province), all the authorities gave evidence against him. According to the local Falange head, "during the period of red domination, he was the leader of the hordes"; the

\footnotetext{
${ }^{72}$ Robert Gellately, The Gestapo and German Society: Enforcing Racial Policy, 1933-1945 (Oxford: Oxford University Press, 1990).

${ }^{73}$ Peter Anderson, The Fracoist Military Trials, by the same author, 'Singling Out Victims: Denunciation and Collusion in the Post-Civil War Francoist Repression in Spain, 1939-1945', European History Quarterly, 39, 1 (2009), 7-26; and 'In the Interests of Justice? Grass-roots Prosecution and Collaboration in Francoist Military Trials, 1939-1945', European Contemporary History, 18, 1 (2009), 24-44. This idea was previously expressed in: Ángela Cenarro, 'Matar, vigilar y delatar: la quiebra de la sociedad civil durante la guerra y la posguerra en España (1936-1948)', Historia Social, 44 (2002), 65-86. Conxita Mir, 'El sino de los vencidos: la represión franquista en la Cataluña rural de posguerra', in Casanova, Julián, ed., Morir, matar, sobrevivir. La violencia en la dictadura de Franco (Barcelona: Crítica, 2002), 123-93. Francisco Cobo Romero, 'Represión y persecución de minorías y disidentes en las dictaduras fascistas europeas del periodo de entreguerras. (Los apoyos sociales y la colaboración de ciudadanos comunes. La Alemania 'nazi' y la España Franquista)', Espai/Temps, 45 (2005), 13-50, see 44-9.
} 
COBO ROMERO, Francisco, DEL ARCO BLANCO, Miguel Ángel y ORTEGA LÓPEZ, Teresa, "The Stability and Consolidation of the Francoist Regime. The case of Eastern Andalusia, 1936-50", Contemporary European History, 20, 1, 2011, pp. 37-59.

Civil Guard said that "under Marxist rule he committed all kinds of outrages"; and the mayor stated that this "enthusiastic propagandist and perpetrator of Soviet ideas" opposed the "Glorious Uprising" with the "aim of achieving the installation of a Marxist regime". 75 Arco Soto was taken to the Provincial Prison in Granada. However, in 1945 repression was still underway. Even then, some residents of the town continued to commit themselves to repression: together with the reports of the authorities and inspectors appointed for that purpose, two residents stated that he had no property. ${ }^{76}$

The participation of a section of society in repression went beyond denunciations and statements. Some would even form part of the machinery ensuring residents were stripped of their property, participating in the process of confiscation. The judge would appoint an inspector from among the inhabitants of a place to carry out the appropriate investigations, asking for information from banks and land registry offices, speaking to neighbours, etc. ${ }^{77}$ This arduous task meant an obvious political commitment to Francoism: these men would visit the houses of relations, making an inventory of items of value, contemplating the terrified faces of the Republican families. Supporters of common values and ideas, they did not hesitate to participate in the punishment they considered just and appropriate for the annihilation of a "subhuman Republican enemy". In the town of Montefrío, of the 28 complete files analysed, we find no less than 20 different inspectors; some of them even lent their services to different proceedings. ${ }^{78}$ Both right-wing inspectors and technicians, marked by the experience of the war and repositories of that "culture of victory", did not hesitate to participate in the processes that dispossessed families with a Republican or socialist tradition of their property. For instance, Alfonso Pérez García acted as an inspector in various actions against his neighbours. Farmer and small property owner, he was monarchical councillor for Acción Popular (Popular Action) and head of the Catholic trade union in the town during the Second Republic. At 38, after the uprising, he was arrested by the Republicans; nonetheless, he managed to escape and fled to the rebel area, where he joined the Falange and took up the position of councillor in one of the "New State's" first town councils. By 1940 he was already

\footnotetext{
${ }^{74}$ A pioneering study: Conxita Mir, Fabián Corretgé and Joan Sagués, Repressió económica i franquisme: L'actuació del Tribunal de Responsabilitats Polítiques a la provincia de Lleida (Barcelona: Publicacions de l'Abadia de Montserrat, 1997).

${ }^{75}$ Archivo de la Real Chancillería de Granada (ARChGR), Responsabilidades Políticas file of José María Arco Soto, 5-9-1941, 23-11-1941 and 13-1-1937.

${ }^{76}$ Ibid., Statements of 31-3-1945.

${ }^{77}$ For example: AGA, Justicia, box 256, file of Juan María Álvarez Jiménez.
} 
COBO ROMERO, Francisco, DEL ARCO BLANCO, Miguel Ángel y ORTEGA LÓPEZ, Teresa, "The Stability and Consolidation of the Francoist Regime. The case of Eastern Andalusia, 1936-50”, Contemporary European History, 20, 1, 2011, pp. 37-59.

head of the Montefrío Hermandad de Labradores (Brotherhood of Farmworkers), the agricultural trade union of the Francoist regime. ${ }^{79}$

The division between victors and vanquished became evident. The socioeconomic profile of the accused fitted with that of the Republicans, who belonged to the lower and lower-middle classes: of the 28 defendants, only 10 of them had any kind of property and these people had only small or very small properties. ${ }^{80}$ On the other hand, the inspectors belonged to the modest and heterogeneous middle classes: 18 out of 20 of them would have urban or rural property. ${ }^{81}$

It is clear that Francoism's social supports participated in the regime's values and beliefs, and also the morality that this regime advocated. In this way, many people's behaviour was conditioned by fear and coercion: in Franco's Spain, too, there existed a "selfpolicing society". ${ }^{82}$ It was the very residents of Spanish towns and cities who became the censors of the ideas, attitudes and habits of their fellow citizens. Francoism granted them the possibility of participating in social and moral control, watching over the country's "health" and many did not hesitate to make the most of this opportunity. The fear of being denounced, of being singled out for negative treatment by the authorities, became something widespread and everyday: that time was the beginning of self-censorship, internal exile and, above all, silence. Francoism's supporters thus became repositories of a disciplinary and sovereign power that was able to seal their enemies' fate with the ability to decide between life and death. $^{83}$

\footnotetext{
${ }^{78}$ We refer to 28 'expedientes de incautación de bienes' (property confiscation files) deposited in the AGA, Justicia section, box 256.

${ }^{79}$ Archivo Histórico Provincial de Granada (AHPG), AISS, boxes 7197 and 7218.

${ }^{80}$ Some examples: AGA, Justicia. Comisión Provincial de Incautación de Bienes de Granada. Box 256, file of Antonio Blanco Ruiz, 24-10-1936; and file of Pedro Peregrina Mazuela, 14-12-1936.

${ }^{81}$ AGA, Justicia, box 256. Padrón of the inhabitants of Montefrío, 1922. Catastro de Rústica. Padrón de Urbana of 1940 .

${ }^{82}$ We apply here the concept of Robert Gellately: Backing Hitler: consent and coercion in Nazi Germany, Oxford, Oxford University Press, 2001. This idea has arisen in, among others: Óscar Rodríguez Barreira, “"Cuando lleguen los amigos de Negrín...” Actitudes individuales y opinión pública ante la II Guerra Mundial en una provincia del Sur. Almería, 1939-1945', Historia y Política. Ideas, procesos y movimientos sociales, 18, (2007), 295-323.

${ }^{83}$ Michel Foucault, Hay que defender la sociedad, (Madrid: Akal, 2004), 206.
} 
COBO ROMERO, Francisco, DEL ARCO BLANCO, Miguel Ángel y ORTEGA LÓPEZ, Teresa, "The Stability and Consolidation of the Francoist Regime. The case of Eastern Andalusia, 1936-50”, Contemporary European History, 20, 1, 2011, pp. 37-59.

\section{The political economy of "Franco's Justice": satisfying the interests of the victors and destroying the vanquished}

Participating and collaborating with the regime's institutions, Francoism's social supports would obtain their own "Justice" in material terms. In the context of the terrible economic crisis of the post-war period, they would see their private interests fulfilled, obtaining a just reward for their contribution to installing the regime and ensuring its permanence. In this sense, too, those who had lost the war would also face their neighbours, the victors, and suffer the terrible consequences of the political autarchy.

There has been criticism of the irrationality of the autarchy's economic model. ${ }^{84}$ These points of view, as well as failing to take into consideration the autarchical model's cultural and political goals, have focussed their analyses on the economic results obtained by the Spanish economy as a whole, showing that certainly economic growth came to a halt and that economic crisis characterised the post-war years. However, a more careful local analysis shows the cultural and political coherence of the autarchical model: Francoism's social bases avoided the poor economic conditions and, in some cases, progressed economically; on the other hand, the most disadvantaged classes came face to face with poverty. ${ }^{85}$ Meanwhile, the "culture of victory" legitimised and sanctioned the enrichment of those who had won the war. It justified the permissiveness of the authorities towards their fraudulent practices and, at the same time, it justified the punishment of the lowest, of those who were never part of the regime's social bases, demanding from them the sacrifice necessary for the economic independence and redemption of Spain.

The autarchy meant the adoption of a highly interventionist system. Suddenly, a regime that affirmed the continuity of the war provided its men with an unprecedented weapon: controlling their neighbours' food supply. It would be these new men, a reflection of Francoism's social bases, ex-combatants marked by the experience of the Civil War and imbued with the official culture of Francoism, who would control the work on, production, sale and distribution of food and products in each area. ${ }^{86}$ The administration of rationing

\footnotetext{
${ }^{84}$ For example, Carlos Barciela and María Inmaculada López Ortiz, 'El fracaso de la política agraria del primer franquismo, 1939-1959. Veinte años perdidos para la agricultura española', in Carlos Barciela, ed., Autarquía y mercado negro. El fracaso económico del primer franquismo, 1939-1959 (Barcelona: Crítica, 2003), 55-93.

${ }^{85}$ Miguel Ángel del Arco Blanco, 'Hambre de siglos'. Mundo rural y apoyos sociales del franquismo en Andalucía Oriental (1936-1951) (Granada: Comares, 2007), 378.

${ }^{86}$ Miguel Ángel del Arco Blanco, “Hombres nuevos": el personal político del primer franquismo en el mundo rural del sureste español (1936-1951)', Ayer, 65 (2007), 237-67. See also: Francisco Cobo Romero and Teresa
} 
COBO ROMERO, Francisco, DEL ARCO BLANCO, Miguel Ángel y ORTEGA LÓPEZ, Teresa, "The Stability and Consolidation of the Francoist Regime. The case of Eastern Andalusia, 1936-50”, Contemporary European History, 20, 1, 2011, pp. 37-59.

cards, which lasted until 1952, was in their hands: the survival of their neighbours depended on their decisions.

The regime's social supports enjoyed the authorities' indulgence. Perhaps the best example of this was the workings of the estraperlo or black market. According to an English traveller writing in 1946, the entire Spanish nation, rich and poor alike, was involved in the black market, yet the army, the authorities, the large Francoist bureaucracy and the regime's social supports were not punished for this. ${ }^{87}$ Those who were caught out were almost always from the lowest classes. In Almeria province, almost 90 out of 100 of those charged belonged to the lowest classes: unemployed, day labourers, workers and a striking number of widows. 86 out of 100 had no property or economic capacities at all. ${ }^{88}$

Furthermore, Francoism's social bases were better equipped to face the situation. The heterogeneous rural middle classes (small and medium-sized traders and industrialists, but above all small and large farmers and even landlords) had access to food resources and products, ensuring their survival through direct consumption or by means of a small black market tolerated by the authorities. It was even possible for some to enrich themselves spectacularly. The municipality of Santa Fe produced some surprising results. Between 1936 and 1951, of the 27 administrators with agricultural interests, 12 of them became property owners or increased the size of their agricultural properties (more than 44 percent), 12 held their properties intact (44.4 percent) and only the properties of three were reduced in size (11.11 percent). ${ }^{89}$ One example is the case of Fausto Rodríguez Rodríguez. In 1936, at 40 years of age, he did not work his own land. After joining the Falange, fighting the Civil War, holding party positions (assistant local head in 1940, head of the Hermandad de Labradores from 1944 to 1960) and being a local councillor between 1944 and 1947, his prospects would improve remarkably. The defence of the "values of the Crusade" and his close adherence to the regime bore fruit: in 1945 he obtained property, a little more than 2 hectares, but in 1951 he had over 12 hectares of agricultural land in Santa Fe alone. ${ }^{90}$

\footnotetext{
María Ortega López, "No sólo Franco. La heterogeneidad de los apoyos sociales al régimen fanquista y la composición de los poderes locales. Andalucía, 1936-1948”, Historia Social, 51 (2005), 49-71.

${ }^{87}$ The National Archives (TNA), FO 371/60377, Report 18-4-1946.

${ }^{88}$ Archivo Histórico Provincial de Almería (AHPA), GC, Almeria Fiscalía Provincial de Tasas Files, 1945, boxes 734 and 735 .

${ }^{89}$ AHMSF, Appendix of the catastro de rústica. AHPG, Hacienda, Catastro de rústica. Cédulas de propiedad. Leg. 223/1 and 223/2.

90 AHMSF, Appendix of the catastro de rústica. AHPG, Hacienda, Catastro de rústica. Cédulas de propiedad. Leg. 223/1 and 223/2; AHMSF, 279 Libro de actas of the Comisión Gestora, Comisión Gestora 26-9-1944; AHPG, AISS boxes 7111, 7219 and 7203 .
} 
COBO ROMERO, Francisco, DEL ARCO BLANCO, Miguel Ángel y ORTEGA LÓPEZ, Teresa, "The Stability and Consolidation of the Francoist Regime. The case of Eastern Andalusia, 1936-50", Contemporary European History, 20, 1, 2011, pp. 37-59.

The socioeconomic repression provides evidence that the culture of victory and social realities went hand in hand. The Montefrío smallholder Alfonso Pérez García, referred to above, collaborated with the Tribunal of Responsabilidades Politicas, persecuting the town's left-wing families. He shared that "culture of victory" and participated in a number of the regime's local institutions. The socioeconomic results of his political loyalty are evident: owning just 0.15 hectares in 1936, in 1946 he farmed 3.72. He shared the values of the Francoist regime, but he also acted to repress the vanquished, thereby obtaining a reward. ${ }^{91}$

Meanwhile, for the vanquished there was only hunger and misery: in short, socioeconomic repression. The lowest classes did not have productive resources. Many families had been destroyed by the execution of the head of the family as well as through the exile or imprisonment of family members. Away from the prisons and cemeteries, life went on: the families of those on the losing side had to avoid hunger and it was necessary to struggle to survive. Great political dreams were forgotten, and replaced with a day-to-day fight that often involved breaking the laws of the day in order to cling to life, carrying out silent resistance that would mark the terrible years of the nineteen-forties. ${ }^{92}$ They resorted to the black market in order to survive, although the authorities, directed by the regime's social supports, were a constant obstacle in this regard. While the great black market, of the large goods vans of wheat, went undetected, the "black market of the poor" was punished with fines which, if unpaid, would mean the accused were taken straight to labour camps. ${ }^{93}$ Repression also occurred outside the prisons: the very legal system was a weapon ready to be used against the weakest. ${ }^{94}$ However, the constant fight against legality would alleviate the conditions of the most underprivileged, as well as involving silent resistance and protest which shows that those who remained outside the community of victory were also present. ${ }^{95}$

The extreme economic situation would condition post-war life. Dying of hunger would become a sad possibility for some. The perpetuation of the regime also worked in this way: not only because, as we have seen, it undermined the majority's dreams of redemption, but also because Francoism took advantage of this situation. The regime's social policy was

\footnotetext{
${ }^{91}$ AHPG, Hacienda, Catastro de rústica. Cédulas de propiedad, Leg. 192/4-192-6

${ }^{92}$ James Scott, Everyday forms of peasant resistance (New Haven: Yale University Press, 1984); and 'Everyday forms of peasant resistance', The Journal of Peasant Studies, 13, 2 (1986), 5-35.

${ }_{93}$ Miguel Gómez Oliver and Miguel Ángel del Arco Blanco, 'El estraperlo: forma de resistencia y arma de represión en el primer franquismo', Studia Histórica. Historia Contemporánea, 23 (2005), 179-99.

94 Juan Francisco Gómez Westermeyer, 'Historia de la delincuencia en la sociedad española: Murcia 19391949’, PhD thesis, Universidad de Murcia, 2006.
} 
COBO ROMERO, Francisco, DEL ARCO BLANCO, Miguel Ángel y ORTEGA LÓPEZ, Teresa, "The Stability and Consolidation of the Francoist Regime. The case of Eastern Andalusia, 1936-50", Contemporary European History, 20, 1, 2011, pp. 37-59.

aimed at creating support: institutions like Auxilio Social (Social Aid) were intended to attract the population, of course attempting to instil the regime's ideology in those who received aid, but also offering paternalist services that would make the difficult post-war conditions lighter. ${ }^{96}$ In Almeria, the Frente de Juventudes (Youth Front) also carried out this role of assistance, and perhaps for this reason it is not surprising that the majority of its militants belonged to the lowest classes or were children of those on the losing side of the Civil War. ${ }^{97}$ Francoism was not averse to carrying out a social or ideological policy in order to integrate and recruit the masses. ${ }^{98}$ Recent research into Seville province seems to indicate that sometimes the regime was successful: we should not ignore the Falangist programme's powers of integration, as shown by the large number of Falange members belonging to the lowest classes. ${ }^{99}$ However, what is certain is that the "discourse of victory", designed to exclude and differentiate, made the integration of the vanquished a complicated matter.

\footnotetext{
95 Ana Cabana, 'Minar la paz social. Retrato de la conflictividad en Galicia durante el primer franquismo', Ayer, 61, (2006), 267-88.

96 Ángela Cenarro, La sonrisa de Falange: Auxilio Social en la guerra civil y en la posguerra (Barcelona: Crítica, 2005), 148-59.

${ }^{97}$ Óscar Rodríguez Barreira, 'El Frente de Juventudes en Almería. Análisis político-social de una delegación de FET-JONS en los 40', unpublished research project, Universidad de Almería, 2002.

${ }^{98}$ Carme Molinero, La captación de las masas: política social y propaganda en el régimen franquista (Madrid: Cátedra, 2005), 210-1.

${ }^{99}$ José Antonio Parejo, Señoritos, jornaleros y falangistas (Seville, Bosque de Palabras, 2008), 95-98.
} 
COBO ROMERO, Francisco, DEL ARCO BLANCO, Miguel Ángel y ORTEGA LÓPEZ, Teresa, "The Stability and Consolidation of the Francoist Regime. The case of Eastern Andalusia, 1936-50”, Contemporary European History, 20, 1, 2011, pp. 37-59.

\section{Conclusion}

During the interwar period, the Western world was shaken by a profound economic, political and cultural crisis. In a context in which the old liberal order suffered from general discredit and the emergence of new political formulas for exalting the Nation, conceived as a live body, and one necessarily provided with a profound cohesion. In this new context, the Fascists turned the traditional forms of political experience around, contributing to the creation of scepticism towards democracy and traditional liberalism's elites, designated as "decrepit" and "ineffective". Fascism had arisen as a movement of political action profoundly imbued with a forceful rejection of the representative and parliamentary system of pre-war liberalism. The Fascists called for a reconceptualisation of the Nation, now understood as a vital community possessing a memorable shared past, and frequently revealed through a copious relation of myths, fables, allegories and symbols.

The rise and installation of Francoism was no exception. Franco's regime was a product of a civil war that involved the crystallisation of an ideology uniting both previouslyexisting and new cultural components with a Fascist or intensely Fascistised origin. In the rearguard and on the front line, a "culture of victory" would be created that, not without difficultly, would grant unity to the rebel group. This culture was not only imposed from above, but it also arose due to a combination of existing traditions and new situations. At that time, mythical and regenerative elements arose that made it possible to see the "Crusade" as the decisive moment when the "true Spain" would rise from its ashes. These visions were embraced by heterogeneous groups on the right wing and by the varied range of social classes who fought to end the Republic. In the clamour of battle, the culture would become an element uniting the victors.

The Civil War ended. Yet Franco's regime advocated the perpetuation of its memory and non-reconciliation: thus the forties became a continuation of this culture of war, of this culture of victory which was a constant reminder of both the "Crusade's" validity and an idea of Spain that discriminated between victors and vanquished. The "community of victory" and its values would remain alive in the post-war period, integrating and giving strength to Francoism's political project.

As some of the local examples given in this article show, the "culture of victory" conditioned the lives, perceptions and actions of Francoism's supporters, making it possible 
COBO ROMERO, Francisco, DEL ARCO BLANCO, Miguel Ángel y ORTEGA LÓPEZ, Teresa, "The Stability and Consolidation of the Francoist Regime. The case of Eastern Andalusia, 1936-50”, Contemporary European History, 20, 1, 2011, pp. 37-59.

for the community of victors and the regime itself to interact. This is an explanation for the direct involvement of many men and women in the work of repression, control and policing of the so-called "enemies of Spain". It would also explain the participation that the regime's social supports were ready to provide in different fields. Through these institutions, the management of power would follow the same logic of the "culture of victory": the victors would negotiate the difficult post-war conditions and even obtain tempting benefits; meanwhile, the vanquished, the lowest classes, would live trapped by poverty and hunger, a continuation of the repressive maze in which they would find themselves in Franco's Spain.

The "culture of victory", constructed on mythical approaches that arose during the Civil War, became an essential element -although not the only one- used by the regime in its search for stability and a long life. Francoism's social supports, those heterogeneous middle classes that actively participated in the movement's birth during the Civil War and in its continuity during the post-war period, extracted from those mythical approaches a "corpus" of ideas and values in which to believe. It was this culture that helped them to interpret the convulsed world in which they lived as a reality that was in need of profound regeneration, giving them the necessary justification to eliminate the enemy and guarantee their own economic progress.

\section{[MAP 1]}

Map 1. Eastern Andalusia: the provinces of Malaga, Jaen, Granada and Almeria

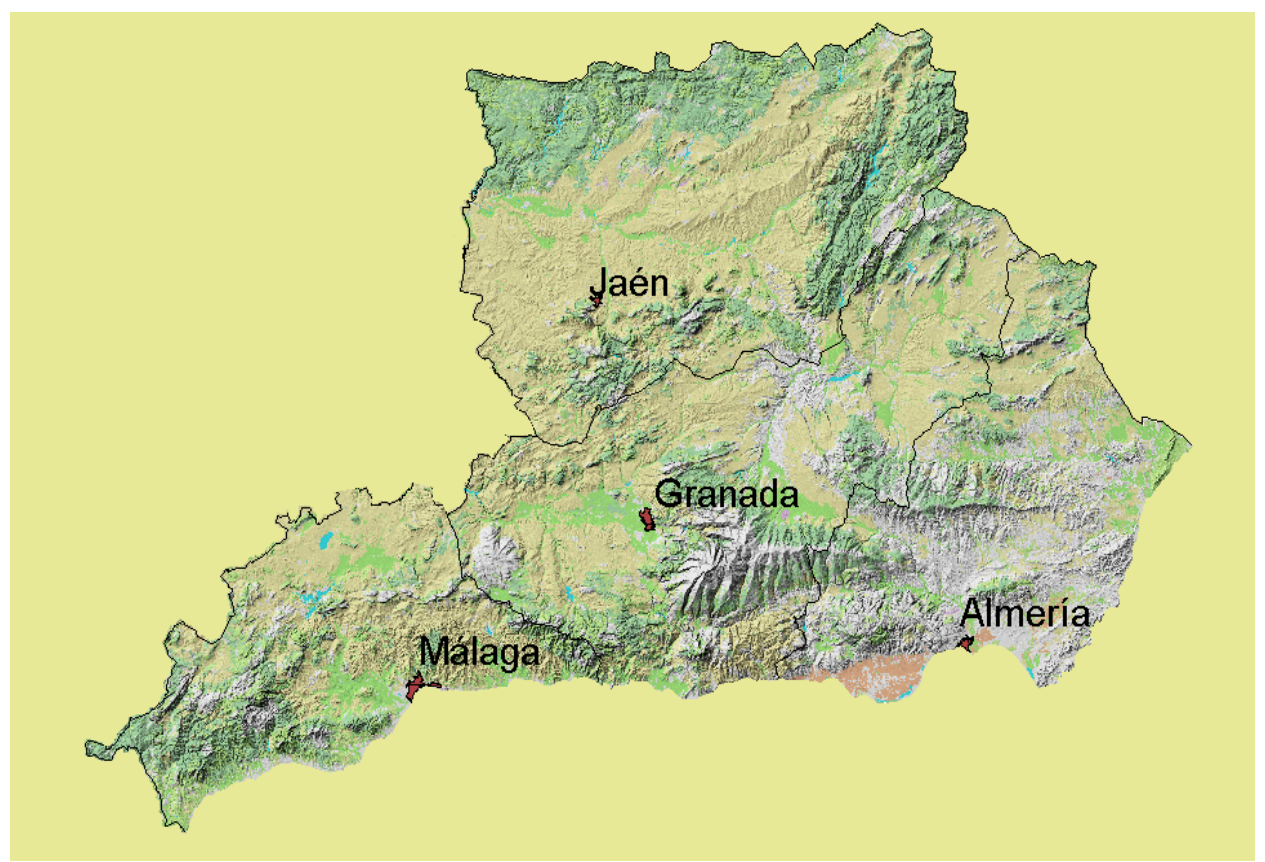

